\title{
Differences in ice retreat across Pine Island Bay, West Antarctica, since the Last Glacial Maximum: Indications from multichannel seismic reflection data
}

\author{
G. Uenzelmann-Neben, ${ }^{1}$ K. Gohl, ${ }^{1}$ R.D. Larter, ${ }^{2}$ and P. Schlüter ${ }^{1}$ \\ ${ }^{1}$ Alfred Wegener Institute for Polar and Marine Research, Am Alten Hafen 26, 27568 Bremerhaven, Germany (Gabriele.Uenzelmann-Neben@awi.de, \\ Karsten.Gohl@awi.de, Philip.Schlueter@awi.de) \\ ${ }^{2}$ British Antarctic Survey, Highcross, Madingley Road, Cambridge CB3 0ET, UK (r.larter@bas.ac.uk)
}

\begin{abstract}
An understanding of the glacial history of Pine Island Bay (PIB) is essential for refining models of the future stability of the West Antarctic Ice Sheet (WAIS). New multichannel seismic reflection data from inner PIB are interpreted in context of previously published reconstructions for the retreat history in this area since the Last Glacial Maximum. Differences in the behavior of the ice sheet during deglaciation are shown to exist for the western and eastern parts of PIB. While we can identify only a thin veneer of sedimentary deposits in western PIB, eastern PIB shows sedimentary layers $\leq 400 \mathrm{msTWT}$. This is interpreted as a result of differences in ice retreat: a fast ice retreat in western PIB accompanied by rapid basal melting led to production of large meltwater streams, a slower ice retreat in eastern PIB is most probably the result of smaller drainage basins resulting in less meltwater production.
\end{abstract}

Citation: Uenzelmann-Neben, G., K. Gohl, R.D. Larter, and P. Schlüter (2007), Differences in ice retreat across Pine Island Bay, West Antarctica, since the Last Glacial Maximum: Indications from multichannel seismic reflection data, in Antarctica: A Keystone in a Changing World - Online Proceedings of the $10^{\text {th }}$ ISAES, edited by A.K. Cooper and C.R. Raymond et al., USGS Open-File Report 2007-1047, Short Research Paper 084, 4 p.; doi:10.3133/of2007-1047.srp084

\section{Introduction}

Pine Island Bay (PIB), located in the Amundsen Sea along the southern Pacific margin of West Antarctica (Fig. 1), is characterized by two major ice streams, Pine Island Glacier (PIG) and Thwaites Glacier (TG), which drain from an area of $\sim 410,000 \mathrm{~km}^{2}$ of the West Antarctic Ice Sheet into the bay. Recently, these ice streams have been subject to rapid basal melting and thinning combined with grounding line retreat (Rignot and Jacobs, 2002). Because the base of the ice is far below sea level in the interior of their drainage basins, both PIG and TG have been considered to be potentially unstable and could undergo partial collapse, which would have a drastic effect on global sea level. In order to provide constraints for models that predict the contribution from the WAIS to sea level rise we have to accurately understand the dynamics and development of PIG and TG in the Late Quaternary.

Previous marine geophysical and geological datasets comprise multibeam swath bathymetry, side scan sonar, TOPAS subbottom profiles, single channel seismic reflection profiles, and geological sampling of limited extent in PIB (Anderson et al., 2001, 2002; Lowe and Anderson, 2002, 2003; Dowdeswell et al., 2006; Evans et al., 2006). A small number of radiocarbon dates on sediment core samples have been published, but unfortunately they are characterized by large uncertainties (Lowe and Anderson, 2002). In common with other shelf areas of Antarctica, PIB deepens inshore due to glacial erosion and lithospheric flexure in response to ice loading. It has been shown that the ice sheet was grounded to the shelf break, at least on the western part of the shelf, during the Last Glacial Maximum (LGM), and was drained by a palaeo-ice stream (Lowe and Anderson, 2002, 2003; Dowdeswell et al., 2006; Evans et al., 2006). Inner PIB shows a rugged seafloor with water depths exceeding $1000 \mathrm{~m}$. A cross-shelf bathymetric trough was identified, which extends NW roughly parallel to $107^{\circ} \mathrm{W}$ and is fed by narrow and deep tributaries emerging from PIG and TG (Lowe and Anderson, 2002, 2003). The seafloor across the middle-outer shelf in eastern PIB was found to be smoother with water depths of 400-600 m (Nitsche et al., submitted).

Lowe and Anderson (2002, 2003) defined four geomorphic zones within PIB (Fig. 1): zones Z1 and Z2 show melt water derived channels and cavities, zone Z3 shows megascale glacial lineations, and zone $\mathrm{Z4}$ is characterized by iceberg furrows. It has been reported that relatively warm Circumpolar Deep Water (CDW) penetrates PIB via the cross-shelf bathymetric trough thus enhancing basal melting of the floating ice shelves and ice tongues (Jacobs et al., 1996; Hellmer et al., 1998).

The evolution of the WAIS is recorded in the subglacial bedforms and sedimentary sequences of PIB. Here we present the first multichannel seismic reflection data from the inner and eastern PIB to enhance our understanding of the glacial developments and processes active there and to extrapolate the results already presented for the middleouter shelf (Anderson et al., 2001, 2002; Lowe and Anderson, 2002, 2003; Dowdeswell et al., 2006; Evans et al., 2006).

\section{Data Acquisition and Processing}

In 2006 the Alfred Wegener Institute for Polar and Marine Research (AWI) in collaboration with the British Antarctic Survey (BAS) collected a set of seismic reflection lines in PIB during RV Polarstern cruise ANTXXIII/4 (Fig. 1). Three GI-guns ${ }^{\mathrm{TM}}$ (total volume 2.21 , frequencies up to $250 \mathrm{~Hz}$ ) generated the seismic signal. This leads to a theoretical vertical resolution of $8 \mathrm{~m}$. The data were received with a 96-channel streamer $(600 \mathrm{~m}$ long). Processing of the data comprised sorting $(25 \mathrm{~m}$ CDP interval), a detailed velocity analysis to take account of the sea floor and subsurface topography (every 50 CDPs), noise suppression via a Karhunen-Loeve 
transform, corrections for spherical divergence and normal moveout, stacking, and time migration applying an Omega-X migration (Yilmaz, 2001).

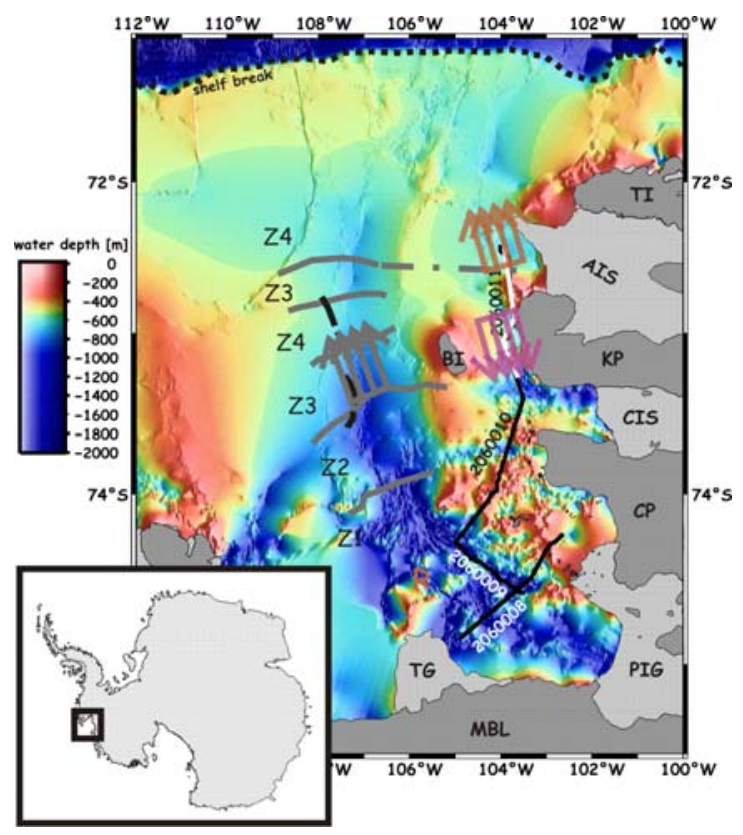

Figure 1. Map of Pine Island Bay showing the location of the seismic lines AWI-20060008 to AWI-20060011 (white part shown in Fig. 3). Bathymetry is from Nitsche et al. (submitted). Z1 to Z4 separated by grey lines show the location of the four geomorphic zones as defined by Lowe and Anderson $(2002,2003)$. The location of the seismic profile presented by Lowe and Anderson (2002, 2003) is shown as dashed black lines. Grey arrows show the onset of the seaward-dipping strata as observed by Lowe and Anderson $(2002,2003)$. Purple and red arrows show the areas where we observe southward and northward dipping sequences in our seismic data. Dashdotted grey line shows the onset of zone Z4 in our data. Dotted line shows the approximate location of the shelf break. R shows the location of a bathymetric ridge across the glacial trough. $\mathrm{AIS}=$ Abbot Ice Shelf, $\mathrm{BI}=$ Burke Island, $\mathrm{CIS}=$ Cosgrove Ice Shelf, $\mathrm{CP}=$ Canisteo Peninsula, $\mathrm{KP}=$ King Peninsula, $\mathrm{MBL}=$ Marie Byrd Land, $\mathrm{PIG}=$ Pine Island Glacier, $\mathrm{TG}=$ Thwaites Glacier Tongue, $\mathrm{TI}=$ Thurston Island.

\section{Observations and discussion}

In general, our seismic lines reveal a very rough seafloor, which is characterized by rugged topography and only a thin veneer of sediments (usually $\leq 75 \mathrm{~ms}$ TWT $\approx 56 \mathrm{~m}$ ). Line AWI-20060008, which cuts across the trough in front of PIG, shows a number of topographic highs cut by channels, which reach water depths of 1200 $\mathrm{m}$ (1600 ms TWT). Towards the north, the trough deepens to water depths exceeding $1400 \mathrm{~m}(1800 \mathrm{~ms}$ TWT). With depths of 150-300 m (200-400 ms TWT), the area in the eastern part of PIB is much shallower.

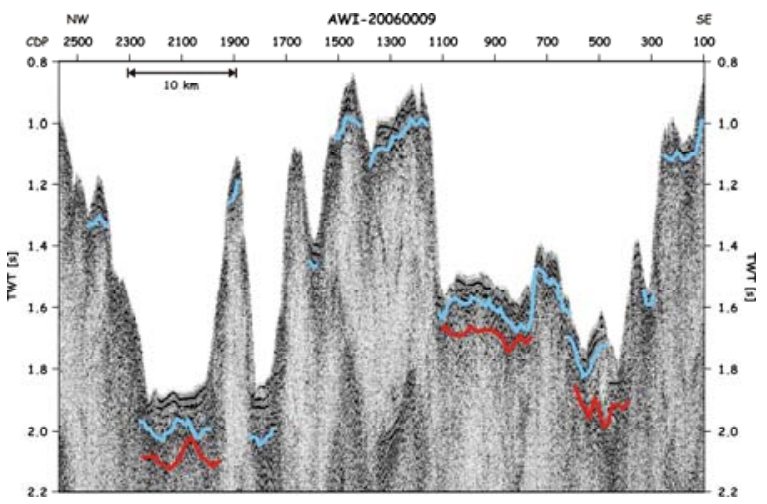

Figure 2. Seismic profile AWI-20060009. For location see Fig. 1. Red line= top of basement, blue line= base of youngest sedimentary sequence. Vertical exaggeration at the seafloor $=40: 1$. A larger image can be seen in Plate 1 .

About $100 \mathrm{~km}$ seaward of PIG ice front we observe a $15 \mathrm{~km}$ wide seafloor high ( $650 \mathrm{~m}$ water depth), which forms a barrier across the trough (R in Fig. 1). Here, we can identify a sediment cover of $75 \mathrm{~ms}$ TWT at most (Fig. 2). In the deeper parts of the trough, sediments with a thickness up to $120 \mathrm{~ms}$ TWT can be observed. In places, an older reflection can be seen, which appears faulted (Fig. 2, CDPs 400-600, 600-1100, 1750-1850, and 20002300).

On our seismic lines the rough seafloor topography can be followed northwards to $73^{\circ} 16^{\prime} \mathrm{S} / 103^{\circ} 42^{\prime} \mathrm{W}$. This point roughly lies on a line connecting the southern coast of Burke Island (BI) with King Peninsula (KP) (Fig. 1). There, we observe a $\sim 66 \mathrm{~km}$ wide high characterized by a smoother seafloor (water depths 525-825 m). Acoustic basement lies 100-400 ms TWT below the seafloor and is faulted (Fig. 3, CDPs 4600-6300 on AWI-20060010 and CDPs 100-700 on AWI-20060011). We can distinguish several internal reflectors defining at least three sedimentary units (Fig. 3). The youngest sedimentary unit is up to $100 \mathrm{~ms}$ thick and thins out both in the north and south (Fig. 3, CDPs $<4600$ on AWI-20060010 and CDPs $>700$ on AWI-20060011) and in the centre of the feature (Fig. 3, CDPs 5500-5800 on AWI-20060010). In general, the reflectors are inclined towards the south.

This feature extends roughly to a line between the northern BI and KP. Further north we observe a rise in the seafloor (up to a water depth of $250 \mathrm{~m}, 37 \mathrm{~km}$ wide, Fig. 3, CDPs 700-2200 on AWI-20060011), again showing rough topography and only a sediment cover of max. 75 ms TWT. Further north again, seaward of Abbot Ice Shelf (AIS), the seafloor is smooth once more (Fig. 3, CDPs > 2200 on AWI-20060011). Acoustic basement rapidly plunges to depths of $800 \mathrm{~m}$ below seafloor (mbsf) and more. Again, a number of internal reflections can be identified defining at least three sedimentary units. The older sedimentary units show an inclination towards the north while the youngest sedimentary unit rests unconformably on top (Fig. 3, CDPs $>2300$ on AWI20060011). 


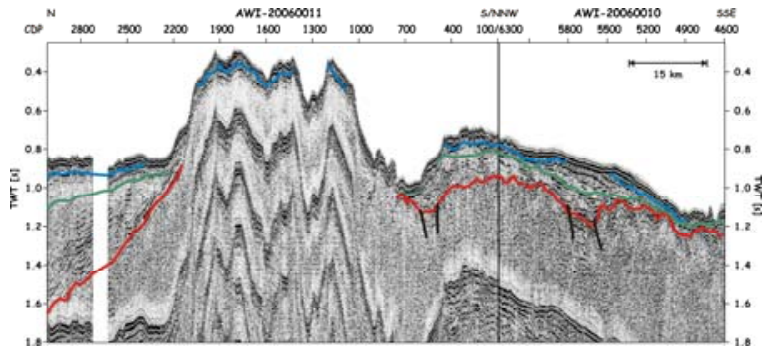

Figure 3. Seismic profile AWI-20060010/ 20060011. For location see white line in Fig. 1. Note the southward dipping sequences in the southern part of the profile. Northward dipping strata can only be observed between CDPs 400 and 700 as well as north of CDP 2200. Red line $=$ top of basement; green line $=$ intra-sedimentary reflection, blue line $=$ base of youngest sedimentary sequence. Vertical exaggeration at the seafloor $=44: 1$. A larger image can be seen in Plate 2.

As mentioned previously, the southern PIB is characterized by rugged seafloor topography. We observe deep channels within the main glacial trough interpreted as having been formed by subglacial erosion. Lowe and Anderson $(2002,2003)$ present detailed multibeam swath bathymetric mapping of this glacial trough and describe its channel incision by erosional processes through subglacial melt water streams. They put forward a geomorphic division of PIB (grey lines and zones Z1-Z4 in Fig. 1) with deep melt water channels and cavities for zone Z1 (inner shelf) and melt water channels for zone Z2 (middle shelf). Lowe and Anderson $(2002,2003)$ further report that in zones $\mathrm{Z1}$ and $\mathrm{Z} 2$ crystalline basement is exposed.

Our seismic data show a cover of less than $75 \mathrm{~ms}$ TWT of young sediments in the larger channels, while the smaller channels appear to be void of sediment (our seismic source signal resolves layers thicker than $3 \mathrm{~m}$ ). A reason for this may be that the melt water rushed much faster through the narrow channels hence eroding most of the sedimentary cover while slightly calmer conditions (wider channels lead to lower flow velocities) allowed deposition of young sediment in the wider parts of the glacial trough. Strong fluctuations in flow rates may also have contributed to the lack of sediments in the smaller channels.

The ridge-like feature extending across the glacial trough at about $74^{\circ} 23^{\prime} \mathrm{S} / 104^{\circ} 30^{\prime} \mathrm{W}$ rises up to a water depth of $650 \mathrm{~m}$ (R in Fig. 1, CDP 1150-1550 in Fig. 2). From the seismic image we interpret this feature as a basement structure. This structure may have acted as a pinning point for grounded ice and led to a pause in grounding line retreat. The location of this structure coincides roughly with the ice grounding line suggested by Lowe and Anderson $(2002,2003)$ for a second phase of ice retreat following the LGM, which is consistent with our interpretation of the ridge-like feature as a former pinning point.
For the area west of Burke Island, Lowe and Anderson $(2002,2003)$ report a distinct change in basal conditions from exposed crystalline basement to seaward dipping strata. This is expressed in the onset of zone Z3 (Fig. 1, grey arrows; Lowe and Anderson, 2002, 2003). Here, they observe a widening but also a decrease in relief of the glacial trough. No melt water channels are observed; it is suggested that melt water was incorporated into the sedimentary layers thereby changing the mechanism of sliding (Anderson et al., 2001; Lowe and Anderson, 2002, 2003). Streaming ice is implied (Anderson et al., 2002).

Our seismic lines AWI-20060010 and AWI20060011, which were collected east of Burke Island (Fig. 1), show a distinctly different picture with southward dipping reflections and a broad seafloor high (purple arrows in Fig. 1, Fig. 3, CDPs 4600-6300/100700). We observe seaward dipping strata north of Burke Island (red arrows in Fig. 1). Furthermore, we can identify a sedimentary cover of up to $400 \mathrm{~ms}$ TWT (Fig. 3 , CDPs 4600-6300/100-700). Here, the seafloor is smooth and the subsurface is characterized by several continuous internal reflections. Those reflection characteristics argue against a rapid erosion, e.g. by melt water streams. This indicates that the region between Burke Island and King Peninsula was more sheltered and not subject to rapid ice retreat and subglacial melt water streams. We propose that the fill of this trough was not completely eroded during prior glacial advances. Lowe and Anderson $(2002,2003)$ also suggest a continued ice cover in this area after initial ice retreat following the LGM and a later evacuation.

Melt water streams as reported for the Pine Island glacial trough appear to have occurred in the area east of Burke Island only in limited numbers, if at all, and were not as powerful as the ones in southern PIB even though a smaller glacial trough extending from Cosgrove Ice Shelf (CIS) and reaching water depths of $800 \mathrm{~m}$ can be observed (Fig. 1). PIG and TG are much larger glaciers with larger drainage basins than those flowing into CIS. Hence, there is the potential for a larger amount of melt water to be gathered beneath PIG and TG. Additionally, the larger depth of the ice beds of PIG and TG will tend to lead to stronger melting of those glaciers compared to those flowing into CIS. Where basal erosion takes place creating troughs, basal melting and streaming flow develop preferentially along such troughs resulting in more erosion thus deepening them, which makes them even more likely to be sites of ice streams during subsequent glaciations.

Northwards of $72^{\circ} 35^{\prime} \mathrm{S} / 103^{\circ} 48^{\prime} \mathrm{W}$ we also observe seaward dipping strata (red arrows in Fig. 1, Fig. 3, CDPs 2200-3100). The inclined sedimentary layers are covered unconformably by aggradational young sediments. This is the same seismic structure as observed in the northern zone Z4 of Lowe and Anderson (2002, 2003). Those zones defined by Lowe and Anderson $(2002,2003)$ are seafloor geomorphic zones. Lowe and Anderson (2002, 
2003) linked those geomorphic zones to subsurface characteristics observed in their seismic data (Fig. 10 in Lowe and Anderson, 2003), which offers a possibility to correlate structures observed in our seismic data with the geomorphic zones. We hence extend their northern boundary Z3/Z4 further to the east (Fig. 1, dash-dotted grey line). The small area between CDPs 400 and 700 on line AWI-20060011 may be considered as an equivalent to zone Z3 of Lowe and Anderson (2002, 2003). There, we observe slightly seaward dipping reflectors without a young sedimentary cover. This is the same seismic structure Lowe and Anderson (2002, 2003) report for zone Z3. As already pointed out, we do not observe a grounding zone wedge, which would indicate a pause in retreat of the grounding line after the initial retreat from the shelf break (Lowe and Anderson, 2002, 2003). This further argues for a variation in the ice retreat process in the different parts of PIB.

\section{Conclusion}

New multichannel seismic reflection data have shown that eastern PIB was subject to a different glacial development from western PIB during the Late Quaternary. While the seafloor is dissected by melt water channels and cavities that discharged into a glacial trough in western PIB, the eastern part of the bay shows a much smoother topography. Here, up to $400 \mathrm{~ms}$ TWT of sediments can be observed, whereas the wider channels in the west show only $75 \mathrm{~ms}$ TWT of sediment or less and the smaller channels are void of sediments.

We relate this difference in late glacial evolution to the influence of the different drainage areas. The smaller drainage basin of CIS led to the production of less melt water compared to PIG and TG. Furthermore, PIG and TG are much thicker glaciers resulting in stronger basal melting, which in turn creates troughs, streaming flow, more erosion and hence a positive feedback. North of
Burke Island both western and eastern PIB show a more uniform structure.

Acknowledgements. We are grateful for the excellent support of Captain Pahl and his crew of RV Polarstern during data collection. We further thank Alan Cooper, John Anderson and Eugene Domack for their helpful comments. This is AWI contribution No. awi-n16562 and a contribution to the BAS GRADES-QWAD project.

\section{References}

Anderson, J.B., Wellner, J.S., Lowe, A.L., Mosola, A.B., and S.S. Shipp (2001), Footprint of the expanded West Antarctic Ice Sheet: Ice stream history and behavior, DSA Today, 10, 4-9.

Anderson, J.B., Shipp, S.S., Lowe, A.L., Wellner, J.S., and A.B. Mosola (2002), The Antarctic Ice Sheet during the Last Glacial Maximum and its subsequent retreat history: A review, Quat. Sci. Reviews, 21, 49-70.

Dowdeswell, J.A., Evans, E., Ò Cofaigh, C., and J.B. Anderson (2006), Morphology and sedimentary processes on the continental slope off Pine Island Bay, Amundsen Sea, West Antarctica, GSA Bulletin, 118, 606-619.

Evans, J., Dowdeswell, J.A., Ò Cofaigh, C., Benham, T.J., and J.B. Anderson (2006), Extent and dynamics of the West Antarctic Ice Sheet on the outer continental shelf of Pine Island Bay during the last glaciation, Mar. Geol., 230, 53-72.

Hellmer, H.H., Jacobs, S.S. and A. Jenkins (1998) Oceanic erosion of a floating Antarctic glacier in the Amundsen Sea, in Jacobs, S.S. and R.F. Weiss (eds), Ocean, Ice, and Atmosphere: Interactions at the Antarctic continental margin, Antarctic Research Series, 75, AGU, 83-99.

Jacobs, S.S., Hellmer, H.H. and A. Jenkins (1996), Antarctic ice sheet melting in the southeast Pacific, Geophys. Res. Lett., 23, 957-960.

Lowe, A.L., and J.B. Anderson (2002), Reconstruction of the West Antarctic ice sheet in Pine Island Bay during the Last Glacial Maximum and its subsequent retreat history, Quat. Sci. Reviews, 21, 1879-1897.

Lowe, A.L., and J.B. Anderson (2003), Evidence for abundant subglacial meltwater beneath the paleo-ice sheet in Pine Island Bay, Antarctica, J. Glaciology, 49, 125-138.

Nitsche, F.O., Jacobs, S., Larter, R.D., and K. Gohl, (submitted), A new bathymetry compilation for the Amundsen Sea and its implication for regional oceanography and geology, Geochemistry Geophysics Geosystems.

Rignot, E. and S.S. Jacobs (2002), Rapid bottom melting widespread near Antarctic ice sheet grounding lines, Science, 2020-2023.

Yilmaz, Ö., 2001, Seismic Data Analysis. Investigations in Geophysics, 10: Society of Exploration Geophysicists, Tulsa, $2027 \mathrm{p}$ 